\title{
Esophageal Tissue
}

National Cancer Institute

\section{Source}

National Cancer Institute. Esophageal Tissue. NCI Thesaurus. Code C32543.

The tissue of the esophageal wall. It is composed of mucosa, a muscular coat, and a serosal surface. 